\title{
THE ESSENCE, PREMISES AND PERSPECTIVES OF MODERNISATION OF THE EUROPEAN UNION
}

\author{
by Józef M. Fiszer
}

\section{INTRODUCTION}

Modernisation of the European Union or just another modification? Such a dilemma appears regularly during all inter-governmental conferences, specially before and after approving another revision treaty for the European Union. To answer such a question, first the essence and meaning of these terms has to be explained, and to do so, the best option is to refer to their etymology. And so, according to the PWN "Dictionary of Foreign Words", 'modification' "latin modification=measuring " is a change, transformation, remake; a modified object, while 'modernisation' »fr. moderne $=$ modern $"$ is making something modern or making something contemporary'.

Therefore, modernisation shall mean a broader and deeper process, these are actions leading to radical transformations and changes as compared to modification, which usually precedes modernisation. It may then be said that as far as the European Union is concerned, commencing from

\footnotetext{
1 See Słownik wyrazów obcych PWN, J. Tokarski (ed.), Warszawa 1980, pp. 484-485.
} 
its origination by the Maastricht treaty of $7^{\text {th }}$ February 1992 till the latest revision treaty, i.e. the Lisbon treaty which became effective on $1^{\text {st }}$ December 2009, we only witnessed its successive (permanent) modification, that is slow transformations which were generally named extension and enhancement processes. Today, after nearly twenty years of remakes and use, the European Union needs not only a radical overhaul but rather modernisation, meaning its update and adapting to contemporary times. Today, the European Union requires adaptation to challenges and requirements of the $21^{\text {st }}$ century determined by acceleration and globalisation progressing within all spheres of life.

Modernisation has been a long-known category in the field of international relations science or political science, but only recently has it been making an enormous career in internal and foreign policies of particular states. This term is also used by politicians and columnists, especially during election campaigns or during breakthrough periods for states and nations, e.g. during crises or revolutions. Colloquially, the essence of states' modernisation is referred to as deep, radical reforms and building a new social, political and economic order, and they are either required or promised to be introduced after taking power. This is exemplified by the 1986 modernisation of the USSR announced by Mikhail Gorbachev which entered the history under key words of "perestroika" "glasnost" and "uskarene" - that is reconstruction, transparency and democratisation of social, political and economic life of that country ${ }^{2}$. Unfortunately, it ended up with a catastrophe, a collapse of the USSR, which despite its superpower status disappeared from the global political map ${ }^{3}$.

In 1999, i.e. the moment when he became the prime minister, and then in 2000 when he was elected president, Vladimir Putin announced modernisation of the Russian Federation and, alas, it did not work ${ }^{4}$. In 2010

\footnotetext{
2 See M. Gorbaczow, Przebudowa i nowe myślenie dla naszego kraju i dla całego świata, Warszawa 1988; M. Tatu, Gorbatcher. L'U.R.S. S va-t-elle changer?, Paris 1987.

3 See among: D.R. Marples, Historia ZSRR. Od rewolucji do rozpadu, Wrocław 2006; W. Marciniak, Rozgrabione imperium. Upadek Związku Sowieckiego i powstanie Federacji Rosyjskiej, Kraków 2004.

4 See among: J.M. Fiszer, Władimir Putin - dlaczego zaufała mu cała Rosja? Specyficzne formy przywództwa politycznego, [in:] Przywództwo i elity polityczne $w$ krajach
} 
modernisation of Russia was proclaimed by the new president Vladimir Medvedev but so far nothing has been done in internal and foreign policy to achieve that.

Whereas, for twenty years the People's Republic of China has been successfully modernising, with its national economy experiencing a specific miracle as today it is among the fastest-growing economies in the world. A strategic purpose of the recently published another five-year development plan for China for 2011-2015 is bringing Yuan to international markets which, in other words, shall become an international currency and may endanger the position of the US dollar ${ }^{5}$. The Chinese are also modernising their army. They are replacing heavy equipment, e.g. tanks, building an aircraft carrier and stealth planes ${ }^{6}$. Slowly the social and political system of the PRC is being modified, though the country remains a communist state ${ }^{7}$.

Modernisation of the US has also been announced by president Barack Obama, but its realisation is obstructed by the financial and economic crisis which has been shaking America since 2007.Modernisation is demanded by rebels of Tunisia, Egypt, Morocco, Yemen and Libya who caused the outbreak of the Arabic spring of nations in 2011. Today it is difficult to say whether their dream shall come true.

Then, if everyone is modernising, then the European Union must not only modify its system and improve the expensive policies which are in permanent crisis anyway. Does the European Union need modernisation today? Certainly yes, but it should be wise, well thought out and prepared and then consistently implemented. The Union must not repeat M. Gorbachev's or V. Putin's errors, and modernisation must not end up with its erosion and destruction as consequences would be terrifying for Europe and the entire world.

WNP, eds. T. Bodio, W. Jakubowski, Vol. II, Warszawa 2010; A. Bryc, Rosja w XX wieku. Gracz światowy czy koniec gry?, Warszawa 2008.

5 See R. Romanowski, Juan będzie już wkrótce walutą światową, "Puls Biznesu”, 30.05.2011.

6 See J. Winiecki, Nowe skrzydła smoka, "Polityka", 12.02.2011.

7 See J. Feny, Chiny. Upadek i narodziny wielkiej potęgi, Kraków 2009. 


\section{THE EUROPEAN UNION TODAY AND PREMISES FOR ITS MODERNISATION}

So far, we have faced in the European Union evolutionary transformations and changes regarding its composition and political system, legal system, decision-making processes as well as internal and external policy. As a result, the Union has become a global economic power but is still a political dwarf, a minor division player on the global political arena. Its position in international relations was not strengthened by the long-awaited Lisbon treaty which gave the Union legal personality and made it subject to international law and international relations. Today, the European Union is unofficially said in Beijing and Washington to be weak, divided, inconsequent and duplicitous. Many even foresee its end. Right is then a question by Timothy Garton Ash: "Why we, Europeans, cannot act together towards the world? We have done so much at home - we are about to close the most ambitious expansion of the Union in history, we are celebrating the $10^{\text {th }}$ anniversary of the Euro. But in foreign policy we are merely a step ahead than a decade ago. (...) Facing the growing power of China and India, the relative power of Europe is inevitably shrinking (...). If we, Europeans, do not get a grip on ourselves, our American, Chinese and Russian 'friends' shall have reasons to despise us"8.

I believe it will not be that bad. Europeans notice common threats and global problems and are aware that construction of a new, democratic global order where the European Union shall play one of the key roles should be accelerated. Therefore, the Union, its structures and policies must be reformed, improved and modernised, it makes no sense to only criticise and destroy what we have already managed to achieve. First of all, the Europe "heads of states and governments" has to be rebuilt into the Europe of citizens. The Union has to develop towards a Europe of citizens, create common public opinion and build a European community of political, economic and social interests together with a community of

8 See T.G. Ash, Unia zostaje w tyle, “Gazeta Wyborcza”, 10-11.01.2009. 
values ${ }^{9}$. Shortly speaking, today the European Union is facing great challenges and problems, it needs far-reaching modernisation.

Increasing EU from 15 to 25 and then to 27 states was a great, unprecedented event in the history of European integration and international relations. It became a turning point in the process of unification of our continent and overcoming the times of divisions and the cold war. In the global scale, the potential and international position of the European Union remarkably increased and it became the strongest player on the international arena ${ }^{10}$.

After its recent expansion, the European Union has become the biggest economic zone in the world which produces $30 \%$ of the global GDP and makes $17 \%$ of the global trade. The per capita income in the new member states increased from $40 \%$ of average income in the "old EU" in 1989 to $52 \%$ in 2008. The average economic growth in the years 2004-2008 was 5,5\%, and from 1999 till 2003-3,5\%. In most politicians' and experts' opinions, the recent accessions brought Europe notable benefits and strengthened its position in the world. This made it one of the most important pillars of the new international order which is being shaped in the world today ${ }^{11}$.

There is a dominating view that the European Union shall become a still more important centre of influence upon the shape and course of global international affairs. Today it is already the biggest community in the world which merges features of developed international organisation with a federal structure of a union state. So it has sill stronger attributes of a global player and competencies to actively participate in international relations. EU should then aspire not only to maintain but to increase its presence in all regions of the world. It should rationally bind a commercial policy, developmental and humanitarian aid with expanding political and

9 See P. Mikiewicz, Kierunki ewolucji Unii Europejskiej na tle wyzwań globalnych, "Przegląd Politologiczny" 2010, No. 4, pp. 34-40.

10 See J.M. Fiszer, Konsekwencje polityczne członkostwa Polski w Unii Europejskiej. Fakty i mity, [in:] Polska w Unii Europejskiej. Aspekty polityczne, międzynarodowe, społeczno-gospodarcze i wojskowe, ed. J.M. Fiszer, Warszawa 2009, p. 13.

11 See S. Konopacki, Pięć lat po akcesji, "Przegląd Polityczny” 2009, No. 7, p. 7. 
diplomatic activities, as for many years the United States has been doing and as China has done recently. This may allow EU to become an important "stabiliser", a centre of political influence on a global scale and impact the shape of a new international order simultaneously being one of its key poles (pillars).

The presented, relatively positive image of the European Union does not mean though that it shows no weaknesses and deficiencies. After the recent expansions, the Union lost its vigour and vision, it is struggling in a political provisional existence trying, with continuously growing effort, to balance national egoisms. Numerous crises of each of the so called Union policies - energy, immigration, fiscal, climatic, defence, etc. make governments reach rather for their own national tools, rather than for Community ones. The currency crisis in the Euro zone is not only exacerbating but is starting to undermine the foundations of the entire European Union. The biggest member states challenge not only economic but also political and social pillars of a united Europe. The Community system does not work, new demarcation lines appear, and the biggest states in the European Union change their alliances. In Greece, Ireland and Portugal, the fate of both the Euro zone and the entire European Union hang in the balance. Serious rumbles come from Italy, the Union's third economy, which may follow Portugal. Over 20\% unemployment in Spain causes anxiety. France and Germany are moving further away from each other while they are the two most important states in the Union, a tandem which so far has been its driving force. De facto, it was Germany who for decades made the foundation, also the financial one, of unifying Europe, and today it openly presents its sense of harm and a weakening belief in a sense of driving the entire cracking machinery which the European Union resembles today.

German-French differences in opinions often reach beyond the personal animosities of both leaders: France, despite German objection, joined the war in Libya, the Germans abandon their nuclear power system neglecting the French opinion. In April 2011, Nicolas Sarkozy contacted the Italian prime minister Silvio Berlusconi demanding restrictions of free people transfer in Europe (the Schengen zone), one of the most important pillars of the European Union. The next in line may be the common mar- 
ket.The French-German split is a result of the latest system changes (modifications) The Lisbon treaty created an inter-governmental Europe where the European Commission, a traditional opponent to governments, is but a shadow of the old power, and leaders fight with each other. Growth of the meaning of populist parties and movements throughout Europe brought back the rhetoric of "national interest" and has intensified ritual attacks against the Union bureaucracy ${ }^{12}$.

As the events showed related to the French and Dutch "no" to the constitutional treaty of 2005 and the Irish objection to the Lisbon treaty in 2008, expressed in national referenda, in the European Union states a remarkable percentage of citizens do not accept the pace or direction towards which the project of European integration is heading.Even in the repeated Irish referendum of 2009, over $30 \%$ of votes were cast against the Lisbon treaty. Euroscepticism is now an important problem which may halt the integration processes and create new dilemmas for a united Europe which have not been experienced before.

Simultaneously, as it can be seen from the example of Greece, none of the big problems which the union governments face cannot be solved on their own only. Today, there are no influential political movements or leaders in Europe who would propagate a will to restrict state sovereignty in favour of common, Union institutions. Nowadays, in the European Union there is less and less solidarity, coherence and belief regarding its perspectives. The union's enemies comprise not only Eurosceptics but also realists who can easily find arguments that it all looks bad so we should take care of our own interest and grab whatever we can or at least not let

12 See: A. Moroska, Prawicowy populizm a eurosceptycyzm (na przykładzie Listy Pima Fortuyna w Holandii i Ligii Polskich Rodzin w Polsce), Wrocław 2010; H.G. Betz, Warunki sukcesu (klęski) - populistycznych partii radykalnej prawicy we spółczesnych systemach demokratycznych, [in:] Demokracja w obliczu populizmu, eds. Y. Meny, Y. Surel, Warszawa 2007, pp. 273-275; C. van der Eijk, M. Franklin, Potential for Contestation on European Matters At National Elections in Europe, [in:] European Integration and Political Conflict, eds. G. Marks, M.R. Steenbergen, Cambridge 2004, pp. 31-33; A. Kopka, Populizm lewicowy w Europie na przykładzie partii "Die Linke" w Republice Federalnej Niemiec, "Przegląd Politologiczny" 2010, No. 4, pp. 79-96. 
others grab anything from us. Now, the crises-torn, and tired crossroads facing the European Union needs today to refresh forgotten words, concepts and emotions which used to motivate for efforts to build a unified, democratic and rich Europe ${ }^{13}$.

Sławomir Sowiński writes: "The European Union is a historic experiment and a phenomenon where a quite strong economic and political community is built not on the basis of a community of national experiences but in a sense against them. A bond of this supranational political and economic unity shall be not only common interests but also shared values. In other words, the reason why a German pensioner should share their Euro with a Greek student, and a Swedish or French businessman contribute to building roads in Poland or Bulgaria should not only be a common European interest (good holidays in Greece with a comfortable transit through Poland), but also common European identity, responsibility, solidarity and subsidiarity"14.

Now, the deepest crisis in the European Union is the crisis of values and Union axiology, or rather no axiology at all. As a result, inhabitants of this common European home feel more and more strange here, behave still more egoistically, neglect the common fate, achievements and future. It is becoming still more difficult for the inhabitants of the Union building to expand it further so that the rest of the European family could find their place here. On the contrary, ideas of returning to "old good" national times, national colours and national currencies are becoming more and more popular. Therefore, it is high time to start a serious debate on basic values in the European Union. About what the European identity, responsibility and solidarity are today and what should become of them. What obligations do they impose on the richer and what on the poorer members of the European family? Without a reliable naming, recalling or re-dis-

13 W. Malendowski, Suwerenność państw w procesie integracji europejskiej, [in:] "Przegląd Politologiczny" 2010, No. 4, pp. 7-20; W. Smoczyński, Europa się chwieje, “Polityka”, 29.06.-5.07.2011; J. Baczyński, Czy porwiemy Europę?, "Polityka”, 6-12.07.2011.

14 Patrz S. Sowiński, Kościół szansa polskiej prezydencji, prezydencja szansą Kościoła, [in:] Od akcesji do prezydencji. Kościót katolicki w Polsce i Unia Europejska, eds. P. Burgoński, S. Sowiński, Toruń 2011, s. 114-115. 
covering of the European identity, the Union will not be able to operate normally, solve its economic, social and political problems effectively, expand and develop or modernise and this may soon result in its even stronger paralysis or even destruction.

\section{PERSPECTIVES OF MODERNISATION OF THE EUROPEAN UNION}

The European Union, in order to be able to modernise itself, urgently needs not only new axiology and more democracy but also a new approach to democracy and new visionaries, leaders, moral and political authorities. It certainly also needs new reforms and a new strategy which should focus on the citizens and their problems. A remarkable improvement of the financial situation in democratic countries, and only such states as there are in European Union, allows some social stabilisation. Concurrently, today in the European Union countries, a gap is increasing between the behaviour of the elites and those who are lower in the social hierarchy. Such an approach by the elites, Poland included, is well characterised by the saying that simple folk will take everything for granted. However, the folk are not simple enough that they would not see what is exemplified by demonstrators and people fighting for their rights in the streets of Greece, Portugal, Spain and countries of North Africa and the Close East. And they are often trying to release their humiliation upon "others", "strangers", i.e. gastarbieters (guest workers) or immigrants. And not only upon them ${ }^{15}$.

Ever since the times of Alexis de Tocqueville it has been well known that if you want stabilisation then democracy is the best method as it removes influences of a revolutionary spirit. A guarantee for democratic stability should not only be looked for in the "hard" zone of social and

15 See: A. Domasłowski, Widmo buntu krąży po Europie. Wrze w Hiszpanii, Grecji, Portugali, "Polityka", 1-7.06.2011; K. Kubiak, Źródła ludowego gniewu, "RAPORT. Wojsko. Technika. Obronność”, No. 2/11; P. Biernacka, Tunezja czyli od czego się zaczęło, "Stosunki Międzynarodowe" 2011, No. 71-72. 
political institutions but also in the "soft" zone of culture and habits. The great system where the fate of the community is entrusted to the general public shall not last if the seed of democracy falls on a socially infertile land. With advantageous conditions created by a supportive exterior, progressing wealth, expiring nationalisms and fanaticism, the "hard" zone of institutions and the "soft" one of democratic culture support each other and cool down the level of class, political, religious, ethnic and racial conflicts which are dangerous for democracy. Even democratic and stable America was, in A. Tocqueville's opinion, put at risk not by excess of democracy but rather by its deficit. As professor Jan Baszkiewicz correctly notices: "Dependence between chances of democratic stability and cooling down the temperature of conflicts gives a deep sense for concepts taken within the Euro-American culture that democracy is the ruling of a majority which respects justified rights of a minority"16.

The European Union, as I have already mentioned, requires today further strengthening of the Community structures and common shaping of a European and global awareness among its members states and their citizens. The Union also suffers serious problems with shaping Community justice, defence and foreign policy systems as it is not a state, while the Western European integration, whose crowning phase is the EU, took place under the protective shield of NATO where the key role was played by the United States. That resulted in making the EU and Europe's defence system dependent on an external superpower which did not belong to the integration structures. As a result, EU, or broadly Europe, still cannot define "who we are?" and the term "fortress Europe", though seldom used in recent times in the European Union, in the non-European countries remains a synonym of its non-openness to the world and globalisation.

It is an open secret that the European Union is at a crossroads, but many do not admit it. The old, post-war concept by Schuman and Monet does not fit the new $21^{\text {st }}$ century challenges.It has turned out that the federalist concept of creating a "still closer union" and which has been the driving force for European integration for the last sixty years is no longer a per-

16 See J. Baszkiewicz, Gaśnie duch rewolucji, [in:] S. Zawiślański, Trudne łatwe czasy. Rozmowa z humanistami, Warszawa 2011, p. 42. 
manent method for further measures. This idea has been exhausted. The concepts "the bigger, the better" and "the universal approach" are not valid any more.

A responsible reaction to the current situation is finding a new definition of cooperation among European nations. A new balance is needed between the power exercised at EU level and the competencies of member states. This approach should create a proper balance between care for the EU to posses resources and capabilities to look after issues which impact all member states and protection of their national independence ${ }^{17}$.

However, the intellectual concept which is the basis for EU integration is still the federalist idea. It seems that this situation is impossible to change, as any debates about the future of the EU lack courage and a fresh approach. Additionally, the situation is strengthened by the conduct of EU institutions. Both the European Commission and the European Parliament have turned into self-affirming institutions which promote their own interests and programmes at the citizens' expense. This increases the differences between perception and reality in the case of EU and citizens of its member states. This phenomenon is proven by attendance at European Parliament elections constantly falling since 1979. So, the social perception of the EU is remarkably insignificant. European integration, to a large extent, is becoming an elite project which is hardly comprehensible for the citizens. If this status continues then the basis of the EU shall be gradually undermined which shall increase protectionist and nationalist tendencies. Therefore, new, stronger leadership must be established as soon as possible which shall be ready to change the current EU paradigm and define a new vision for its development. The European Union must become more open, flexible, transparent, efficient and responsible, capable to provide the citizens of its member states with high quality services but simultaneously the process of its excessive interferences in competencies of the member states has to be stopped.

\footnotetext{
17 See J.M. Fiszer (ed.), Bilans pierwszych lat członkostwa Polski w Unii Europejskiej, Warszawa 2011, pp. 12-13.
} 
Moreover, continuation of internal reforms of functional or neofunctional nature or actions taken within the Common Foreign and Security Policy should not be treated as a sole factor which conditions the creation of the EU as a "superpower". Europe and the European Union should offer the world their new identity as soon as possible. However, the way of discussing the identity should be changed ${ }^{18}$.

Also, there is an urgent need to intensify scientific research which shall analyse and describe processes of European integration as they are perceived by societies and political elites from various participants of international relations. This research should explain basic controversies related to the perception of Europe and the European Union. It should aim at a complex analysis of perception of Europe by external entities together with pointing out any factors which contribute to strengthening and for cooperation and coexistence together with conditions to create international alliances within or with structures of integrated Europe. Without such an analysis, which would clarify the perception of Europe and the EU by the international environment, there is no option to strengthen the EU position in the world and to face global challenges, which has for many years been declared by heads of governments and states from the European Union.

As Stanisław Parzymies writes: “The European Union is still looking for its place and role on the international stage. This applies to both prevention of all kinds of threats and the form of relationship with such renowned powers as the United States and the Russian Federation as well as newly arising powers such as China, India, Brazil or South Africa. It is acting more intensively the bigger the number of its members is, the larger the area is expanding, the more remarkable its share in international trade is becoming, and the European Security and Defence Policy (ESDP) provokes questions about its destiny. In a situation, when the European Union is addressed by various parties with requirements regarding crisis management, the European Council, during its session in Brussels on $11^{\text {th }}$

18 See A. Giddens, Europe in the Globar Age, UK-USA 2006, pp. 123-124; J. Zielonka, Europa joko imperium. Nowe spojrzenie na UnięEuropejska, Warszawa 2006; M. Cichocki, Północ i Południe. Dwie Europy, "Gazeta Wyborcza”, 21.07.2010, p. 16. 
and $12^{\text {th }}$ December 2008, announced a new impulse for the ESDP by strengthening and optimising in the shortest time European capability and readiness to act for international peace and security. Altogether, the European Union is expected to define its own identity and unity in actions towards the external world"19.

Toady, the European Union must first of all come out stronger in the financial crisis and cope with the economic recession and to reinforce its position on the political map of the world. This may be achieved e.g. by cooperation with the United States, Russia and China. Sergey Karaganov, one of the most renown political scientists, is right when writing about necessary political cooperation between Russia and the European Union: "During the last half of the year, many European politicians and intellectuals have declared a fast rapprochement with Russia. Without understanding of our mutual interest and without long-term strategic goals we shall not overcome the drift and we shall not avoid further marginalisation in the world. A shadow shall be cast over the great 500 years of Europe, and the United States and China shall give a tone to the world. This may not be a great disaster, but such a bipolar world shall be extremely unstable. A triangle USA - China - united Europe may make it more stable. That is why Russia and Europe should strive to create a common Union of Europe and to include there the states which have not yet declared their orientation: Turkey, Ukraine, Kazakhstan, etc. We should aim at a union, not bureaucratic forms, a partnership, be it only strategic. This shall not be easy, but the game is worth the candle. (...) In the future world, Russia and Europe (EU) if acting against each other shall be condemned to degradation and weakness. That is irrational and unwise" 20 .

After its initial years in the European Union and with the experience already gained, Poland also needs to find its place in the Union and establish goals which we shall be consequently trying to achieve in subsequent

19 See S. Parzymies, Unia Europejska jako uczestnik stosunków międzynarodowych, [in:] Dyplomacja..., p. 15.

20 See S. Karaganow, Europa i Rosja. Postawmy na Zwiazek, "Gazeta Wyborcza", 28-29.08.2010, p. 19. 
years and which shall help us to strengthen our position on the international arena. Considering the currently changing power distribution in the world and the shaping of new multipolar international order, the foundation of Polish foreign policy, including its Union policy, should include the following assumptions: firstly - cooperation with neighbours and countries in the region; secondly - cooperation with the European Union; thirdly - NATO has to remain the foundation for the Polish security policy; fourthly - Poland should develop cooperation and thorough relationships with the United States, but should not support such aspects of the American foreign and security policy which do not serve the interests of the West or international stability, undermine reliability of the United Nations and aim at causing divisions in Europe and in the world; fifthly - Poland must not fail to notice Russia and ignore its presence in Europe and in the world. On the contrary, we should strive for an agreement and comprehensive cooperation with Russia, both bilateral and unilateral within the EU and on equal terms.

Poland, being a medium-size state, with its economic, territorial, demographic, military and other potentials, can and should successfully act as a leader in Central-East Europe or even as a local superpower gathering around itself such states as: Lithuania, Latvia, Estonia, the Czech Republic, Slovakia, Hungary, Slovenia, Romania, Bulgaria and the Scandinavian states.

\section{CONCLUSION}

The 2009 European parliamentary election, together with the Lisbon treaty coming into force on $1^{\text {st }}$ December 2009, constituted a turning point in the history of the European Parliament but also in the history of European integration and its outcome - the European Union. That is because the process of reforming the EU which lasted for over ten years was completed, provided we assume that the Amsterdam treaty of the EU which came into power on $1^{\text {st }}$ May 1999 was the first phase of adapting the European Union established on the basis of the Maastricht treaty to new challenges and needs. Another step was the treaty of Nice on the 
European Union of 2000 and the commonly named constitutional treaty of 2004, but none turned out to meet the expectations of all the EU members. In spite of that, a basis was created for further modification and modernisation of the Union so that it may be able to meet expectations of all the members and be the pillar for the new global order. The Lisbon treaty which radically reforms Union institutions made the European Union capable of competing and cooperating with the biggest parties in international relationships, effectively face any challenges and become one of the most important pillars in the new, multipolar international order shaping the world. Such challenges come from both the situation in the Union itself and also relate to its international environment. In the first instance the point is in strengthening the Union cohesion, increasing its capacity to make decisions on the basis of a qualified majority, equalising the level of economic and social development among the member states, effective work of the Union as a zone of democracy, peace, justice, security, respecting human rights as well as an area of solidarity in military and energy security. In the second one - to ensure for the EU the possibility to act its due role in the globalised world. It means creating conditions for the Union to wield remarkable influence upon international processes and co-shaping of the new international order where Europe will not be marginalised or endangered by new powers and decision-making centres. These conditions have already been outlined in the "Europe 2020" strategy, approved by the European Council in March 2010, which is a continuation of the Lisbon strategy of 2000, as renewed in $2005^{21}$.

As Maciej Duszczyk writes: “The "Europe 2020" strategy was developed during the global economic crisis, which despite intentions of its authors to avoid making it the main point of reference, had to impact its shape. The strategy (...) defines main priorities in the economic and social development for the next decade. The crisis time allowed to stress more the issues which without such a perspective would not be placed in the docu-

21 See: J. Ciechański, Problem modernizacji Unii Europejskiej w świetle strategii Europa 2020. Problem zmiany paradygmatu integracyjnego, [in:] Strategia rozwoju Unii Europejskiej, eds. J. Adamowski, K.A. Wojtaszczyk Warszawa 2010, pp. 387-432; M. Duszczyk, Od Strategii Lizbońskiej do Europa 2020 - lekcja dla Unii Europejskiej, [in:] ibidem, pp. 433-451. 
ment. (...) That applied specially to social challenges related on one hand to demographic processes, and on the other to growing competitions from states where incomparable standards of labour laws or social insurances are in force. The Lisbon strategy failed mainly due to three reasons. Firstly due to the mushrooming number of goals which often were contradictory to each other. Secondly, due to political conflicts regarding the so called "European social model" which pushed the need to modify the Lisbon strategy to the background. And finally - a weak position of the European Commission which was unable to force the member states to take actions they had undertaken to do. It seems that the three problems were properly addressed in the "Europe 2020" strategy to which the Lisbon treaty contributed by transferring subsequent competences to Community level. This, however, does not guarantee success for the strategy, which anyway depends on the determination of the member states in realisation of their national actions focused on a growth of competition"22.

In order to make this strategy successful and contribute to modernisation and updating the European Union, which is necessary anyway, the decision-making parties responsible for its practical realisation should become aware that European integration is first of all a social process. This refers to entire societies of the EU member states and to all spheres of life: economic, political, social, cultural and broadly understood sense of security. Until now, the integration driving force included narrow, proEuropean elites gathered mainly in EU institutions and bodies and spread in bureaucracy as well as elites of politics, business and culture in particular member states. Europeans, the EU citizens, are the object of the process and not its subject. Most of the so called common folks in the countries which belong to the European Union either are unaware of their participation in the Europe integration processes or are sceptical towards the concept of unification of our continent. Such a status must quickly be changed and integration and the European Union must serve people, all citizens and not just the elites. This way any modernisation processes in the EU must head.

22 See M. Duszczyk, Od Strategii Lizbońskiej do Europa 2020..., pp. 450-451. 